\title{
IDENTITAS KEINDONESIAAN DALAM NOVEL KARYA ANAK INDONESIA
}

\author{
Suyatno \\ FBS Universitas Negeri Surabaya \\ email: yatno.unesa@gmail.com
}

\begin{abstract}
Abstrak
Penelitian ini bertujuan mendeskripsikan identitas keindonesiaan dalam novel karya anak Indonesia. Sumber data adalah sebelas novel anak berbahasa Indonesia yang dipilih secara acak. Data yang digunakan adalah informasi keindonesiaan yang terdapat dalam narasi novel. Pengumpulan data menggunakan teknik baca dan teknik catat. Analisis menggunakan teknik analisis tematis dengan langkah-langkah: pendeskripsian struktur, penginterpretasian struktur, pemaknaan tematis, penyimpulan tematis, dan pengaitan dengan aspek lain. Hasil penelitian sebagai berikut. Pertama, identitas keindonesiaan meliputi aspek kebangsaan dan kenegaraan. Identitas kebangsaan ditandai oleh penggunaan bahasa Indonesia, seni batik, permainan tradisional, seni wayang, adat Jawa dan Sunda, nasionalisme, dan sosial. Identitas kenegaraan meliputi: Pancasila, bahasa Indonesia, negara Indonesia, kota di Indonesia, dan bendera merah putih. Kedua, identitas keindonesiaan dalam novel karya anak dikembangkan melalui dialog, narasi, dan deskripsi.
\end{abstract}

Kata kunci: identitas keindonesiaan, novel karya anak, kebangsaan, kenegaraan

\section{INDONESIAN IDENTITIES IN NOVELS BY INDONESIAN CHILDREN}

\begin{abstract}
This study aims to describe Indonesian identities in novels by Indonesian children. The data sources were 11 randomly selected Indonesian child novels. The data comprised Indonesian information in novel narration. The data were collected through reading and noting techniques. They were analyzed using the thematic analysis technique through the steps of: describing the structure, interpreting the structure, giving thematic meanings, drawing thematic conclusions, and relating themes to other aspects. The findings are as follows. First, Indonesian identities include aspects of nationalism and statehood. The former is characterized by the use of the Indonesian language, batik art, traditional games, shadow puppet art, Javanese and Sundanese traditions, nationalism, and social affairs. The latter includes: Pancasila, the Indonesian language, Indonesian state, cities in Indonesia, and the red and white flag. Second, Indonesian identities in novels by children are developed through dialogues, narration, and description.
\end{abstract}

Keywords: Indonesian identities, novels by children, nationalism, statehood

\section{PENDAHULUAN}

Identitas keindonesiaan sebagai bangsa dan negara belakangan ini mengalami penurunan. Penurunan itu ditandai oleh lemahnya pemahaman negara bangsa yang menyatukan ribuan pulau, ratusan suku, ratusan bahasa daerah, aneka budaya dan seni, serta multiadat. Bentrokan antarsuku semakin marak. Ketidakpercayaan warga kepada pemimpin bangsa sangat terlihat. Pemahaman terhadap dasar negara, Pancasila mulai lemah. Bah- 
kan, ada warga Indonesia yang tidak hafal Pancasila sebagai dasar negaranya.

Identitas keindonesiaan dalam banyak aspek seperti ideologi, politik, ekonomi, budaya, keamanan, dan sebagainya, telah mengalami degradasi dan bahkan menghilang (Oetama dalam Syahnakri, 2007). Berbagai masalah itu timbul karena jati diri bangsa mulai meluntur. Ikatan sebagai bangsa semakin memudar. Begitu pula, ikatan sebagai warga negara Indonesia semakin tidak dijalankan dalam kehidupan sehari-hari. Peraturan seakan hanya sebagai dokumen resmi di lemari tanpa terlihat dalam pelaksanaan dalam kehidupan bermasyarakat.

Masyarakat Indonesia masa kini sesungguhnya bukan lagi merupakan konstruksi pluralisme tradisional, suku, agama, atau ras, tetapi merupakan konstruksi neopluralisme. Artinya, struktur kemajemukan masyarakat saat ini tidak lagi bersifat massa, tetapi semakin spesifik terpecah menjadi kelompok-kelompok kecil.

Peta pluralisme pun menjadi semakin kompleks. Hamengkubuwono X (2008:5) menyebutkan ketika banyak daerah yang melepaskan diri dari induknya menjadi provinsi atau kabupaten baru, dan banyaknya permasalahan bangsa yang tak kunjung ada solusinya, terasakan bahwa keindonesiaan memang perlu dirajut kembali. Berdasarkan pendapat tersebut keberagaman justru cenderung menyempit, mengkristal dalam kelompok. Ironisnya, keberagaman terkadang hanya sekadar dimaknai bahwa orang lain tidaklah lebih baik daripada kelompoknya sendiri. Di sisi lain, rajutan historis dan pluralisme tidak tumbuh dengan baik sehingga keindonesiaan yang terbentuk belum sepenuhnya utuh. Akibatnya, seperti yang terjadi saat ini, bangsa Indonesia terkotak-kotak sehingga identitas keindonesiaannya pun rapuh. Sebaliknya, politik identitas dalam format identitas suku daerah dan agama mudah menguat, misalnya dalam istilah putra daerah. Tuntutan pemekaran daerah pun sering kali dipicu oleh menguatnya politik identitas itu.

Kondisi pemahaman yang lemah terhadap Indonesia tersebut tentunya akan tercermin ke dalam hasil karya warga Indonesia. Namun, sebaliknya, justru keindonesiaan menguat dalam karya-karya warga Indonesia.Untuk itu, diperlukan kajian tentang identitas keindonesiaan dalam karya-karya warga Indonesia. Salah satu karya warga Indonesia itu adalah karya sastra yang berbahasa Indonesia. Di antara karya sastra tersebut terdapat novel karya anak.

Saat ini, banyak novel karya anak yang diterbitkan dan beredar di masyarakat. Novel tersebut tentunya mempunyai warna tersendiri sesuai dengan kejiwaan dan usia perkembangan anak. Salah satu warna novel tersebut tentunya adalah identitas keindonesiaan yang dituangkan ke dalam narasi novel karya anak itu. Norton (1988:6) menyebutkan bahwa sastra anak dapat mengembangkan nilai bahasa, kognitif, kepribadian, dan sosial anak untuk tahapan usia berikutnya dengan ciri perkembangan berbeda-beda antara anak yang satu dengan anak lainnya.

Novel karya anak berisi ide dan persepsi anak yang berbentuk narasi yang ditulis dalam bentuk cerita. Freeman dan Lehman (2001:1) menyebutkan bahwa dunia sastra anak mempunyai ciri unik bagi dunia anak yang merupakan refleksi cara pandang anak dalam masyarakat dan kehidupan anak-anak. Novel karya anak merupakan cerita prosa tentang perasaan dan pengalaman yang dapat pahami melalui pandangananak (Huck dkk., 1987:10; Bunanta, 1998:31; Nurgiyantoro, 2005:11).

Berkaitan dengan hal tersebut, identitas keindonesiaan saat ini juga terdapat dalam diri anak-anak dalam persepsi dan tindakannya. Untuk itu diperlukan upaya untuk melihat identitas keindonesiaan 
melalui novel karya anak. Tulisan ini melihat bagaimanakah identitas kebangsaan Indonesia dalam novel karya anak? Pertanyaan berikutnya adalah bagaimanakah identitas kenegaraan Indonesia dalam novel karya anak? Tujuan yang dicapai adalah (1) menemukan identitas kebangsaan Indonesia dalam novel karya anak dan (2) menemukan identitas kenegaraan Indonesia dalam novel karya anak.

Keindonesiaan adalah penanda Indonesia dari sisi identitas kebangsaan dan kenegaraan yang lengkap dan utuh. Identitas kebangsaan merujuk pada bangsa dalam pengertian politik, yaitu bangsanegara. Bisa saja dalam negara hanya ada satu bangsa (homogen), tetapi umumnya terdiri atas banyak bangsa (heterogen). Karena itu, negara perlu menciptakan identitas kebangsaan atau identitas nasional, yang merupakan kesepakatan dari banyak bangsa di dalamnya.

Pengertian identitas kebangsaan dikemukakan oleh Wibisono (2005) sebagai manifestasi nilai-nilai budaya yang tumbuh dan berkembang dalam aspek kehidupan suatu bangsa (nation) dengan ciri-ciri khas yang berbeda dengan bangsa lain dalam kehidupannya. Indikator yang dijadikan parameter untuk mencari identitas kebangsaan antara lain: (1) Pola perilaku yang terwujud melaluiaktivitas masyarakat sehari-hari. Hal ini menyangkut adat-istiadat, tata kelakuan dan kebiasaan;

(2) Lambang-lambang yang merupakan ciri dari bangsa dan secara simbolis menggambarkan tujuan dan fungsi bangsa; (3) Alat-alat kelengkapan yang dipergunakan untuk mencapai tujuan seperti bangunan, teknologi, dan peralatan lain; dan (4) Tujuan yang ingin dicapai suatu bangsa yang sifatnya dinamis dan tidak tetap seperti budaya unggul, prestasi dalam bidang tertentu.

Identitas kebangsaan dapat berasal dari identitas satu bangsa yang kemudian disepakati oleh bangsa-bangsa lainnya yang ada dalam negara itu, atau juga dari identitas beberapa bangsa yang ada kemu- dian disepakati untuk dijadikan identitas bersama sebagai identitas bangsa. Kesediaan dan kesetiaan warga bangsauntuk mendukung identitas kebangsaan perlu ditanamkan, dipupuk,dan dikembangkan terus-menerus. Pada konteks ini, perlu ditekankan bahwa kesetiaan pada identitas kebangsaan akan mempersatukan warga bangsa itu sebagai "satu bangsa" dalam negara.

Selanjutnya, identitas kenegaraan Indonesia ditandai oleh: (1) Dasar falsafah dan ideologi negara, yaitu Pancasila; (2) Bahasa negara, yaitu bahasa Indonesia; (3) Lagu kebangsaan, yaitu Indonesia Raya; (4) Lambang negara, yaitu Garuda Pancasila; (5) Semboyan negara, yaitu Bhinneka Tunggal Ika; (6) Bendera negara, yaitu Merah Putih; (7) Hukum dasar negara (konstitusi), yaitu UUD 1945; (8) Bentuk negara, yaitu NKRI dan bentuk pemerintahannya Republik; dan (9) Konsepsi wawasan nusantara, yaitu sebagai cara pandang bangsa Indonesia mengenai diri dan lingkungannya yang serba beragam dan memiliki nilai strategis dengan mengutamakan persatuan dan kesatuan bangsa, kesatuan wilayah dalam penyelenggaraan kehidupan bermasyarakat, berbangsa, dan bernegara, untuk mencapai tujuan nasional; dan (10) Beragam kebudayaan daerah yang telah diterima sebagai kebudayaan nasional.

Tentunya, identitas keindonesiaan juga terdapat dalam novel karya anak Indonesia yang tergambarkan lewat cerita dari awal sampai akhir. Identitas keindonesiaan tersebut dapat dikenali melalui dua aspek, yakni kebangsaan dan kenegaraan. Anak Indonesia sejak lahir sampai besar telah mengenal dan menginternalisasikan identitas tersebut ke dalam bahasa yang digunakan, budaya yang melingkupinya, adat istiadat keluarganya, agama yang dianutnya, bendera negara yang dikenalnya lewat bangku sekolah, lagu kebangsaan, dan ciri kebangsaan dan kenegaraan lainnya. 
Setidaknya terdapat dua hal yang selama ini dianggap sebagai pembentuk identitas keindonesiaan. Yang pertama adalah proses kolonialisasi dan yang kedua adalah kesadaran anak "elit" pribumi atas identitasnya. Identitas keindonesiaan terbentuk melalui sebuah proses evolusi kesadaran anak-anak bangsa yang terkonstruksi dalam historisitas waktu.

Novel anak adalah prosa yang mempunyai tema, alur, tokoh, dan latar yang ditulis untuk anak, berisi tentang dunia anak dan sekelilingnya. Novel tersebut hanyalah dapat dinikmati anak dengan bimbingan orang dewasa (Sarumpaet, 1976: 12; 2003:108; Bunanta, 1998:31). Dengan demikian ciri esensial novel anak adalah penggunaan pandangan anak atau kacamata anak dalam menghadirkan cerita dan dunia imajinasi (Huck dkk., 1987:6). Novel karya anak mempunyaijalan cerita yang runtut, logis, dan lengkap (Suyatno, 2009:20).

Novel karya anak dapat diproduksi oleh anak-anak karena usia anak yakni 6-12 tahun mempunyai ciri (1) perkembangan bahasa anak berlangsung dan terus meningkat; (2) Banyak kata-kata baru masuk ke dalam perbendaharaan kosakata anak; (3) Anak telah menggunakan kalimat-kalimat kompleks dengan panjang rata-rata kalimat yang digunakan 7-8 kata; (4) Anak mulai menghubungkan konsep-konsep dengan ide atau gagasan umum; dan (5) Perbendaharaan kata yang dimiliki sampai sebanyak 15.000 kata di usia 12 tahun (Norton, 1988:5-10).

Stewig (1980:346-369) merumuskan bahwa tema sastra anak berkisar pada: (1) problem keluarga berupa penerimaan, hubungan dengan anggota keluarga, penerimaan diri sendiri, dan hubungan dengan orang tua, (2) problem di luar keluarga berupa keluarga orang tua tunggal, anak tanpa orang tua, dan perceraian, (3) pengalaman nyata berupa perbedaan fisik dan psikologis, perbedaan sosial dan ekonomi, dan perbedaan geografis, (4) pe- mahaman perbedaan etnik dan religius.

\section{METODE}

Penelitian ini menggunakan metode Grand Concept yang bekerja berdasarkan konsep dasar sastra anak sebagai fokus utama yang memayungi pemaknaan kehidupan berbangsa dan bernegara anak Indonesia yang tercermin dalam novel karya anak. Metode tersebut menggunakan teknik analisis tematis novel dengan langkah-langkah: (1) pendeskripsian struktur, (2) penginterpretasian struktur, (3) pemaknaan tematis, (4) penyimpulan tematis, dan (5) pengaitan dengan aspek lain.

Penelitian ini menggunakan sebelas novel karya anak sebagai sumber data. Daftar novel yang dijadikan sumber data dalam penelitian ini disajikan pada Tabel 1. Novel tersebut dipilih berdasarkan cara purposif. Data penelitian berupa informasi tentang kehidupan berbangsa dan bernegara anak Indonesia baik berupa fakta verbal atau informasi tulis yang diperoleh dari kata-kata, kalimat, frase, paragraf, gambar, illustrasi, dan tipografi dalam novel karya anak.

\section{HASIL DAN PEMBAHASAN}

Keraguan banyak kalangan tentang kekuatan sikap dan perilaku keindonesiaan anak-anak yang dianggap rendah ternyata tidak terbukti. Anak-anak justru mempunyai nilai keindonesiaan yang kuat dalam dirinya. Hal itu terbukti dari narasi keindonesiaan anak-anak yang dibangun dari unsur sastra, yakni tema, latar, alur, dan penokohan, yang mencerminkan kebangsaan dan kenegaraan.

\section{Identitas Kebangsaan Indonesia dalam Novel Karya Anak}

Tema-tema yang diangkat anak-anak adalah persahabatan, persekolahan dan liburan, hobi, serta tema petualangan. Tema tersebut dikembangkan menjadi sebuah cerita yang lebih kompleks.Tema 
Tabel 1. Judul Novel Karya Anak yang Dijadikan Sumber Data

\begin{tabular}{|c|c|c|c|c|}
\hline No & Judul novel & Tahun & Penulis & Penerbit \\
\hline 1 & Batik Girls & 2013 & Syadrina Rachma $P$. & Jakarta: Dar! Mizan \\
\hline 2 & Congklak Misterius & 2013 & Anjali & Jakarta: Dar! Mizan \\
\hline 3 & Misteri Pulau Bizzy & 2013 & Naddira Syifa Zuhra & Jakarta: Dar! Mizan \\
\hline 4 & The Royal Secret & 2013 & Ranti & Jakarta: Dar! Mizan \\
\hline 5 & $\begin{array}{l}\text { Bola-Bola Mimpi di Kaki } \\
\text { Alif }\end{array}$ & 2013 & Tristan Alif Naufal & Solo: Tigan Ananda \\
\hline 6 & Karateka Cilik & 2012 & Thifal & Jakarta: Dar! Mizan \\
\hline 7 & $\begin{array}{l}\text { Rambut Persahabatan } \\
\text { Minmie }\end{array}$ & 2013 & Syadrina Rachma P. & Jakarta: Dar! Mizan \\
\hline 8 & Superdays in Superschool & 2012 & Irenna Nicole & Jakarta: Bentang Belia \\
\hline 9 & Petualangan Mimi & 2013 & Winny Khadijah L. & Jakarta: Kinomedia \\
\hline 10 & Scopeto Elasre & 2012 & Nada Laila Ayunindia & Jakarta: Dar! Mizan \\
\hline 11 & Peri Biru & 2013 & Sekar Niga & Jakarta: Zettu \\
\hline
\end{tabular}

persahabatan dan petualangan terdapat dalam novel Rambut Persahabatan Minmei, Batik Girl, Congklak Misterius, Karateka Cilik, dan Bola-Bola Mimpi di Kaki Alif. Dari persahabatan yang dibangun anak-anak itu, ada sebuah novel yang bercerita tentang persahabatan lintas negara. Hal itu menandakan bahwa keindonesiaan anakanak tidak saja berkutat pada regional dan nasional melainkan internasional. Hubungan dengan luar negeri tersebut tentu membawa optimistis bagi bangsa Indonesia karena anak-anak sudah mengenal pentingnya hubungan antarnegara. Novel yang mengangkat hubungan dengan luar negeri itu adalah Rambut Persahabatan Minmei.

Multikultural yang menjadi inti pembangunan Indonesia karena terdiri atas banyak suku dan budaya beragam telah merasuk dalam jiwa anak-anak. Ratarata novel anak berkaitan dengan silang hubungan antarsuku dalam persahabatan dan petualangan sehari-hari. Pembiasaan multikultural tersebut tentunya mempunyai nilai yang strategis bagi pembangunan Indonesia masa depan.

Dalam petualangan, anak memberikan contoh pengalaman nyata meskipun juga terdapat cerita yang bersifat khayalan.
Pada tema petualangan biasanya terdapat unsur-unsur keterkejutan yang sangat menegangkan, misalnya petualangan untuk membebaskan seorang sandera. Petualangan yang bersifat khayali terdapat dalam novel yang berjudul Anak Peri Biru dan bercerita tentang seorang anak kecil berusia 8 tahun, bernama Muciya, yang bersahabat dengan jin perempuan yang mempunyai wajah cantik.

Keindonesiaan yang dibangun anakanak terbungkus oleh latar sekolah, rumah, tempat wisata, tempat-tempat budaya seperti kampung batik. Terlihat bahwa batik sebagai hasil budaya Indonesia diangkat oleh anak-anak ke dalam ceritanya. Anak-anak seolah-olah ingin mengatakan bahwa batik merupakan kebudayaan asli Indonesia yang banyak berkembang di masyarakat.

Selain itu, identitas keindonesiaan juga muncul dalam nama sebuah perumahan, yaitu Perum Zamrud Ungu. Indonesia dikenal sebagai zamrud khatulistiwa. Indonesia dilintasi oleh garis khatulistiwa. Namun, anak-anak juga menggunakan latar internasional, yakni planet Hoshida, Jepang, Korea, dan Amerika. Keindonesiaan anak-anak dikembangkan ke dalam latar yang juga menginternasional. 
Alur yang digunakan untuk mengemas keindonesiaan hanya satu tipe, yakni tipe alur maju. Bentuk alur seperti itu memang sudah menjadi ciri khas anak-anak. Alur maju sangat mudah dibuat anakanak dan dimengerti oleh para pembaca yang kebanyakan juga anak-anak. Alur maju dimulai dari suatu peristiwa kemudian bergerak secara linear ke depan. Namun, dari sekian novel, hanya satu novel yang menggunakan alur mundur. Alur ini terdapat dalam novel yang bertema petualangan misterius. Misal seseorang bisa melihat kondisi dirinya ketika masih kecil. Alur seperti ini terdapat dalam cerita-cerita khayali.

Pola penokohan yang dilakukan anakanak dalam karya yang ditulisnya dalam rangka membangun narasi keindonesiaan adalah pola tokoh utama dan tokoh pembantu, tokoh protagonis dan antagonis, dan tokoh anak-anak dan orang dewasa. Tokoh utama biasanya disertai dengan sifat protagonis yaitu menggunakan tokoh yang baik hati, suka menolong, suka membantu teman. Penokohan yang antagonis dapat berupa seorang pencuri, teman yang mempunyai sifat jahat, geng sekolahan yang suka mengganggu, maupun makhluk halus yang mempunyai sifat jahat.

Penokohan protagonis dapat juga berupa tokoh yang memenangkan suatu per- tandingan, misal pertandingan karate. Sang tokoh muncul sebagai juara. Juara tidak harus nomor satu, tetapi dapat juga nomor di bawah nomor satu. Penokohan orang dewasa biasanya berwujud orang tua sendiri, yaitu bapak dan ibu. Tokoh dewasa lain yaitu yang menyertai tokoh orang tua, misal om, tante, mbok, dan sebagainya. Penyebutan tokoh-tokoh tersebut bermacam-macam, ada yang menyebut dengan mama dan papa. Ada juga yang menyebut dengan abah dan umi. Penokohan ada yang menggunakan tokoh yang nyata dan ada juga yang menggunakan tokoh yang khayali, misal seorang peri atau jin. Tokoh jin ini membantu tokoh utama untuk meraih sesuatu. Tokoh peri atau jin berfungsi untuk memenuhi keinginan tokoh utama.

Anak-anak Indonesia ternyata telah mengenal indentitas keindonesiaan dalam novel yang mereka tulis. Identitas keindonesiaan tersebut meliputi kebangsaan dan kenegaraan. Identitas kebangsaan ditandai oleh penggunaan bahasa, seni, adat, agama, kehidupan sosial, dan ideologi. Sedangkan identitas kenegaraan ditandai oleh Pancasila, bahasa Indonesia, lagu kebangsaan, kependudukan, bendera negara Indonesia, lambang negara, dan uang negara.

Identitas kebangsaan yang paling banyak muncul adalah penggunaan ba-

Tabel 2. Identitas Kebangsaan dalam Novel Karya Anak

\begin{tabular}{cccccccccccc}
\hline Identitas & \multicolumn{10}{c}{ Novel } \\
\cline { 2 - 12 } Kenegaraan & BG & CM & MPB & TRS & BMK & KC & RPM & SSS & PM & SE & PB \\
\hline Bahasa & V & V & V & V & V & V & V & V & V & V & V \\
Indonesia & & & & & & & & & & & \\
Seni & Batik & Cong- & Wa- & - & - & - & - & - & - & - & - \\
& & klak & yang & & & & & & & & \\
Adat & Jawa & Jawa & - & - & - & - & Sun- & - & - & - & - \\
& & & & & & & da & & & & \\
Agama & - & - & - & - & Islam & - & - & - & - & - & - \\
Sosial & V & V & V & V & V & V & V & V & V & V & V \\
Ideologi & Nas. & Nas. & - & Libr. & Islam & - & - & - & - & - & - \\
\hline
\end{tabular}


Tabel 3. Identitas Kenegaraan dalam Novel Karya Anak

\begin{tabular}{cccccccccccc}
\hline Identitas & \multicolumn{11}{c}{ Novel } \\
\cline { 2 - 12 } Kenegaraan & BG & CM & MPB & TRS & BMKA & KC & RPM & SSS & PM & SE & PB \\
\hline Pancasila & - & - & - & - & V & - & - & - & - & - & - \\
Bahasa & V & V & V & V & V & V & V & V & V & V & V \\
Indonesia & & & & & & Jawa & Jepang & & & & \\
Lagu & - & - & - & - & - & - & - & - & - & - & - \\
Kebangsaan & & & & & & & & & & & \\
Kependudukan & V & V & - & USA & V & V & V & V & V & - & - \\
Bendera & - & - & - & - & V & - & - & - & - & - & - \\
Negara & & & & & & & & & & & \\
Lambang & - & - & - & - & - & - & - & - & - & - & - \\
Negara & & & & & & & & & & & \\
Uang Negara & - & - & - & - & - & - & - & - & - & - & - \\
\hline
\end{tabular}

hasa Indonesia. Anak-anak menunjukkan kefasihan dalam berbahasa Indonesia yang diwujudkan ke dalam narasi tulis. Kemampuan menggunakan bahasa Indonesia tersebut tentunya membanggakan negara dan bangsa Indonesia.

Bahasa Indonesia di mata anak-anak dimaknai secara polos, lugu, jujur, dan apa adanya. Kalimat bahasa Indonesia mengalir dengan sederhana dan sesekali dibumbui oleh kalimat bahasa Jawa atau Inggris. Namun, bumbu bahasa daerah dan Inggris hanya sebagian kecil sehingga unsur keindonesiaan melalui penggunaan bahasa dalam novel ini begitu terlihat dominan. Kata dari bahasa asing yang muncul di antaranya Thanks, Hello, What's, congklakholic club, Pulau Bizzy, Bizzy Beach, roller coaster, Princces and Princes, Compass Roses Town.

Terdapat pula identitas seni Indonesia dalam dalam novel anak-anak yang ditunjukkan melalui seni batik, permainan tradisional congklak, dan seni wayang (kulit dan golek). Identitas adat yang muncul dari anak-anak dalam novelnya adalah adat Jawa dan Sunda. Adat dari daerah lainnya belum muncul. Kemudian, tidak ada satupun identitas agama yang muncul. Identitas sosial berupa persahabatan, saling menghargai, bangga dengan bangsa sendiri, peduli terhadap orang lain, tolong menolong, banyak teman, pemaaf, popular, mudah dapat teman, toleransi, setia kawan, persahabatan, perdamaian, dan kemandirian. Ideologi sebagai identitas keindonesiaan yang muncul adalah ideologi nasionalis, islam, dan liberal. Kedua ideologi hadir dengan tidak seimbang karena lebih banyak ideologi nasionalisnya.

\section{Identitas Kenegaraan Indonesia dalam Novel Karya Anak}

Selain identitas kebangsaan, dalam novel karya anak-anak juga muncul identitas kenegaraan yang tergambarkan dalam deskripsi cerita, dialog, dan penceritaan lainnya. Identitas kenegaraan yang muncul adalah Pancasila, bahasa Indonesia, Negara Indonesia, Kota di Indonesia (Jakarta, Jogjakarta), dan bendera merah putih.

Dari sisi kenegaraan, anak-anak mulai memahami konsep Pancasila, negara, kota, dan bendera negara. Pancasila sebagai dasar negara diceritakan oleh anakanak, meskipun dalam satu novel, yakni novel BMKA. Pancasila muncul sesuai dengan tema novel, yakni pertandingan tim nasional sepak bola lewat penamaan tin Garuda. Tim Garuda itu menjadi nama kelompok anak. 
Pemahaman itu sangat menggembirakan bagi usaha pemasyarakatan kenegaraan kepada masyarakat luas. Untuk itu, novel karya anak-anak tersebut sangat layak untuk disebarluaskan ke semua sekolah dan kantong baca di Indonesia.

\section{SIMPULAN}

Dari uraian di atas, dapat disimpulkan sebagai berikut. Narasi keindonesiaan dalam novel karya anak dikembangkan ke dalam tema, latar, alur, dan penokohan. Dari sisi tema, narasi keindonesiaan tergambarkan melalui tema persahabatan, persekolahan dan liburan, hobi,serta tema petualangan. Dari persahabatan yang dibangun anak-anak itu, ada sebuah novel yang bercerita tentang persahabatan lintas negara. Dalam petualangan, anak memberikan contoh pengalaman nyata meskipun juga terdapat cerita yang bersifat khayalan. Latar novel yang menggambarkan keindonesiaan dibangun anak-anak melalui latar sekolah, rumah, tempat wisata, tempat-tempat budaya seperti kampung batik. Namun, anak-anak juga menggunakan latar internasional, yakni planet Hoshida, Jepang, Korea, dan Amerika. Keindonesiaan anak-anak dikembangkan ke dalam latar yang juga menginternasional.Alur yang digunakan untuk mengemas keindonesiaan hanya satu tipe, yakni tipe alur maju. Pola penokohan berupa pola tokoh utama dan tokoh pembantu, tokoh protagonis dan antagonis, dan tokoh anak-anak dan orang dewasa

Identitas keindonesiaan dalam novel karya anak-anak meliputi kebangsaan dan kenegaraan. Identitas kebangsaan ditandai oleh penggunaan bahasa Indonesia, seni batik, permainan tradisional, seni wayang, adat Jawa dan Sunda, nasionalisme, dan sosial. Identitas kenegaraan yang muncul adalah Pancasila, bahasa Indonesia, Negara Indonesia, Kota di Indonesia (Jakarta, Jogjakarta), dan bendera merah putih.

Berdasarkan simpulan di atas, berikut ini saran yang disampakan dari peneli- tian ini. Pertama, pengembangan konsep teori sastra karya anak-anak perlu terus dilakukan agar diperoleh rumusan teori sastra anak karya anak-anak yang dapat membedakan dengan teori sastra anak karya orang dewasa. Kedua, mengingat anak Indonesia sangat produktif dalam menuangkan gagasan dalam bentuk novel, diperlukan pembinaan secara luas ke sekolah-sekolah atau kampong untuk penulisasn sastra anak yang dilakukan anak-anak. Ketiga, penanaman kebangsaan dan kenegaraan Indonesia bagi anak perlu terus dilakukan agar warna keindonesiaan di karya anak-anak akan semakin luas dan mendalam. Keempat, di sekolahsekolah, novel karya anak perlu menjadi bacaan wajib bagi anak seusianya, yakni di SD atau SMP.

\section{UCAPAN TERIMA KASIH}

Ucapan terima kasih disampaikan kepada Lembaga Penelitian dan Pengabdian Masyarakat Universitas Negeri Surabaya yang memberikan kesempatan peneliti untuk melaksanakan penelitian Fundamental pada tahun 2012. Hasil penelitian tersebut disarikan ke dalam artikel ilmiah ini. Terima kasih juga disampaikan kepada ketua Jurusan Bahasa dan Sastra Indonesia, Dekan Fakultas Bahasa dan Seni Unesa, dan perpustakaan pusat Unesa yang memberikan kesempatan penulis melakukan penelitian ini.

\section{DAFTAR PUSTAKA}

Bunanta, Murti. 1998. Problematika Penulisan Cerita Rakyat untuk Anak di Indonesia. Jakarta: Balai Pustaka.

Freeman, Evelyn dan Barbara Lehman. 2001. Global Perspectives in Childrens Literature. Boston. Allyn dan Bacon.

Hamengku Buwono X. 2008. Merajut Kembali KeIndonesiaan Kita. Jakarta: Gramedia Pustaka Utama

Huck, Charlotte. S. 1987. Children's Literature. New York: Holt Rinchart and Wiston Inc. 
Norton, Donna E. 1988. Throught the Eyes of a Child: An Introduction to Children's Literature. Ohoi: Charles E. Merrill Publishing.

Nurgiyantoro. 2005. Sastra Anak. Jogjakarta: UGM Press

Sarumpaet, Riris K. 1976. Bacaan Anak. Jakarta: Pustaka Jaya.

Sarumpaet, Riris K. 2003. "Struktur Bacaan Anak". dalam Teknik Menulis Cerita Anak. Penyunting Sabrur R. Soenardi. Jogjakarta: Pinkbooks.

Stewig, John Warren. 1980. Children and Literature. Boston: Houghton Mifflin Company.

Suyatno. 2009. Struktur Narasi Novel Karya Anak. Surabaya: JP Books.
Syahnakri, Kiki. 2007. “Problematika Bangsa dan Reinvensi KeIndonesiaan". Dalam http://www.freelists. org/post/ppi/ppiindia-ProblematikaBangsa-dan-Reinvensi-Keindonesiaan.diakses 28 Maret 2009.

Wibisono, Siswomiharjo Koento. 2005. "Pancasila sebagai Dasar Etika Kehidupan Bermasyarakat, Berbangsa dan Bernegara". Makalah disampaikan pada kursus Calon Dosen Pendidikan Kewarganegaraan yang diselenggarakan oleh Depdiknas Dirjen Dikti di Jakarta pada tanggal 12-23 Desember 2005. 